\title{
Comment on Rosell-Cardona et al. Dietary Spray-Dried Porcine Plasma Reduces Neuropathological Alzheimer's Disease Hallmarks in SAMP8 Mice. Nutrients 2021, 13, 2369
}

\author{
Artemissia-Phoebe Nifli ${ }^{1,2,3,4}$ (D) \\ 1 Faculty of Medicine, University of Thessaly, Viopolis, 41500 Larissa, Greece; nifli@med.uth.gr or \\ f_nifli@hotmail.com \\ 2 Faculty of Nursing, University of Thessaly, Gaeopolis, 41110 Larissa, Greece \\ 3 Department of Agriculture Crop Production and Rural Environment, University of Thessaly, \\ 38446 Nea Ionia, Greece \\ 4 Larissa Association of Alzheimer's Disease and Related Disorders (EENA $\Lambda$ ), Chatzigianni 3, \\ 41221 Larissa, Greece
}

check for

updates

Citation: Nifli, A.-P. Comment on Rosell-Cardona et al. Dietary Spray-Dried Porcine Plasma Reduces Neuropathological Alzheimer's Disease Hallmarks in SAMP8 Mice. Nutrients 2021, 13, 2369. Nutrients 2021, 13, 4053. https://doi.org/ 10.3390/nu13114053

Academic Editor: Panteleimon Giannakopoulos

Received: 31 August 2021

Accepted: 4 November 2021

Published: 12 November 2021

Publisher's Note: MDPI stays neutral with regard to jurisdictional claims in published maps and institutional affiliations.

Copyright: (C) 2021 by the author. Licensee MDPI, Basel, Switzerland. This article is an open access article distributed under the terms and conditions of the Creative Commons Attribution (CC BY) license (https:/ / creativecommons.org/licenses/by/ $4.0 /)$.
Interventions focusing on dementia risk and/or dementia modification in association with senescence are essential, given the unfavourable demographics [1-3].

Single micronutrient or fatty acid supplementation has failed to provide strong scientific evidence. A combination (Fortasyn ${ }^{\mathrm{TM}}$ Connect, Souvenaid ${ }^{\circledR}$ ) produced conflicting results in either prodromal Alzheimer's disease (AD) or mild AD dementia well designed randomized controlled trials [4]. Thus, repurposing other neutraceuticals could be advantageous, as recently reported [5].

The introduction of animal blood in animal feed had been investigated before 1929. Major safety / quality issues have been resolved, justifying its use partly or in toto [6]. For humans, animal blood consumption arose as a vastly controversial, traditional sustainability practice worldwide.

In antiquity, blood was the main ingredient of the "black broth", an everyday preparation relished by Spartan elders sparing the meat, but disgusting to other Mediterraneans [7]. Nowadays, Finland, France, Norway, Poland, Portugal and Sweden survey explicitly households about blood or blood/black food items (pudding/sausages, bread, pancakes) [8], and Bury, Greater Manchester, England, UK has been reported as the "world black pudding capital" [9]! Sweden also allows for black pudding provisions in school lunches once monthly. So, why are we lacking specifics?

Blood containing food items are often grouped under canned meat and meat products, offal, meat dishes or soy bean products (i.e., blood tofu). Some are considered delicacies, thus less accessible, and consumption scarce; European Union has certified Protected Geographical Indication to 23 products [10]. Most important, (raw) blood consumption is usually part of a restricted diet, indicative of food insecurity $[7,11,12]$.

It is possible though that these choices promote survival and health. A raw blood diet in early weaned Maasai babies [11], contributing iron and protein and strengthening the gut barrier, would be a better alternative to the breast milk of a poorly fed mother. Nutrient digestibility and bioavailability may be an issue as well. Inuit have persistently requested access to "country food", especially in health care settings. In Nunavut, hospitals were the first to offer raw bloody meat, fish, skin or offal, and this diet has been considered superior to $i . v$. or parenteral solutions.

Comparing the biological activity among fresh, processed and isolated blood products, and identifying components of particular interest will be challenging. Major plasma proteins are also notorious for their interactions with micronutrients [13], thus probable not to act alone. Furthermore, the limited epidemiological data do not support superior cognitive scores in regions where regular blood consumers reside [1-3], while the 
emergence of African Swine Fever Virus and the amyloidogenicity of prion proteins of resistant species raise severe concerns about potential applications. Regardless, the work of Rosell-Cardona et al. [5] provoked us to revisit an old nutrition landscape with fresh, yet judicious eyes.

Funding: This research received no external funding.

Institutional Review Board Statement: Not applicable.

Informed Consent Statement: Not applicable.

Data Availability Statement: Not applicable.

Conflicts of Interest: The author declares no conflict of interest.

\section{References}

1. Alzheimer Europe. Dementia in Europe Yearbook 2019 "Estimating the Prevalence of Dementia in Europe"; Ref. Ares(2020)52791728/01/2020; Alzheimer Europe: Luxembourg, 2020; p. 108.

2. Petrasek MacDonald, J.; Ward, W.; Halseth, R. Alzheimer's Disease and Related Dementias in Indigenous Populations in Canada: Prevalence and Risk Factors; National Collaborating Centre for Aboriginal Health: Prince George, BC, Canada, 2018.

3. Wittenberg, R.; Hu, B.; Barraza-Araiza, L.; Rehill, A. Projections of Older People Living with Dementia and Costs of Dementia Care in United Kingdom, 2019-2040; CEPC Working Paper 5; London School of Economics and Political Science: London, UK, $2019 ;$ p. 79.

4. Burckhardt, M.; Watzke, S.; Wienke, A.; Langer, G.; Fink, A. Souvenaid for Alzheimer's disease. Cochrane Database Syst. Rev. 2020, 2020, CD011679. [CrossRef]

5. Rosell-Cardona, C.; Griñan-Ferré, C.; Pérez-Bosque, A.; Polo, J.; Pallàs, M.; Amat, C.; Moretó, M.; Miró, L. Dietary Spray-Dried Porcine Plasma Reduces Neuropathological Alzheimer's Disease Hallmarks in SAMP8 Mice. Nutrients 2021, 13, 2369. [CrossRef] [PubMed]

6. Bah, C.S.; Bekhit, A.E.-D.A.; Carne, A.; McConnell, M.A. Slaughterhouse Blood: An Emerging Source of Bioactive Compounds. Compr. Rev. Food Sci. Food Saf. 2013, 12, 314-331. [CrossRef]

7. Plutarch. The ancient customs of the Spartans. In Moralia; Loeb Classical Library; Harvard University Press: Cambridge, MA, USA, 1976; Volume XIII, Part 1, pp. 426-427.

8. Directorate General for Health and Consumer Protection; Directorate C2-Health Information. The DAFNE Food Classification System; European Commission: Luxembourg, 2005.

9. Fludger, S.; Turner, A.-M.; Harvey, R.F.; Haslam, N. Controlled prospective study of faecal occult blood screening for colorectal cancer in Bury, black pudding capital of the world. BMJ 2002, 325, 1444-1445. [CrossRef] [PubMed]

10. EC. eAmbrosia-The EU Geographical Indications Register. Available online: https:/ / ec.europa.eu/info/food-farming-fisheries/ food-safety-and-quality/certification/quality-labels/geographical-indications-register/ (accessed on 30 March 2021).

11. Chege, P.M.; Kimiywe, J.O.; Ndung’U, Z. Influence of culture on dietary practices of children under five years among Maasai pastoralists in Kajiado, Kenya. Int. J. Behav. Nutr. Phys. Act. 2015, 12, 1-6. [CrossRef] [PubMed]

12. Sinclair, H.M. The Diet of Canadian Indians and Eskimos. Proc. Nutr. Soc. 1953, 12, 69-82. [CrossRef]

13. Scheepens, A.; Tan, K.; Paxton, J.W. Improving the oral bioavailability of beneficial polyphenols through designed synergies. Genes Nutr. 2009, 5, 75-87. [CrossRef] [PubMed] 